\title{
Review
}

\section{The conservation status of West Indian palms (Arecaceae)}

\author{
Scott Zona, Raúl Verdecia, Angela Leiva Sánchez, Carl E. Lewis and Mike Maunder
}

\begin{abstract}
The conservation status of 134 species, subspecies and varieties of West Indian palms (Arecaceae) is assessed and reviewed, based on field studies and current literature. We find that $90 \%$ of the palm taxa of the West Indies are endemic. Using the IUCN Red List categories one species is categorized as Extinct, 11 taxa as Critically Endangered, 19 as Endangered, and 21 as Vulnerable. Fifty-seven taxa are classified as Least Concern. Twenty-five taxa are Data Deficient, an indication that additional field studies are urgently needed. The 11 Critically Endangered taxa warrant immediate conservation action; some are currently the subject of
\end{abstract}

ex situ and in situ conservation projects in the region's botanical gardens. We recommend that preliminary conservation assessments be made of the 25 Data Deficient taxa so that conservation measures can be implemented for those facing imminent threats.

Keywords Arecaceae, Caribbean, Palmae, palms, Red List, West Indies.

This paper contains supplementary material that can only be found online at http://journals.cambridge.org

\section{Introduction}

The islands of the West Indies (the Caribbean Islands sensu Smith et al., 2004), comprising the Greater and Lesser Antilles, along with the Bahamas Archipelago, the Turks and Caicos Islands, and Cayman Islands, are recognized as a hotspot of biological diversity with $>50 \%$ endemism in the flora (Biodiversity Hotspots, 2004; Smith et al., 2004). Palms (family Arecaceae or Palmae) are among some of the most conspicuous plants in the region. In terms of ecosystem function, palms are keystone species (Terbough, 1986); moreover, palms are some of the most economically important wild plants, providing extractable resources (fibre, wood, sugar/ alcohol, and animal feed) for people in the region (Read, 1988; Horst, 1997). Palms are also an important part of every tourist's image of a tropical vacation paradise.

There are 21 genera of palms in the West Indies. Of these, Zombia, Hemithrinax and Calyptronoma are endemic.

Scott Zona (Corresponding author), Carl E. Lewis and Mike Maunder IUCN/ SSC Palm Specialist Group, Center for Tropical Plant Conservation, Fairchild Tropical Botanic Garden, 11935 Old Cutler Road, Coral Gables, Miami, Florida 33156, USA. E-mail szona@fairchildgarden.org

Raúl Verdecia IUCN/SSC Palm Specialist Group, Jardín Botánico Las Tunas, Las Tunas, Cuba

Angela Leiva Sánchez IUCN/SSC Palm Specialist Group, Jardín Botánico Nacional, Carr. El Rocío, Km. 3 1⁄2, Calabazar, CP 19230, La Habana, Cuba.

Received 17 April 2006. Revision requested 14 August 2006.

Accepted 6 October 2006.
Recent phylogenetic work has changed the status of one genus formerly regarded as endemic: Gastrococos is now shown to be part of the widespread genus Acrocomia (Gunn, 2004). Taking these changes into consideration, endemism at the generic level is $14 \%$. Several other genera, such as Pseudophoenix, Roystonea, Acoelorraphe and Thrinax, are near-endemics to the West Indies, also occurring in southern Florida, the Yucatán Peninsula, the Atlantic coast of Central America, or the northern coast of South America. The remaining genera are shared with North, Central or South America. The West Indian endemic palm genera have few species, a pattern consistent with most endemic seed plant genera in the region (Francisco-Ortega et al., unpubl. data). There are 134 taxa of palms in the West Indies. A few, such as Acrocomia aculeata, Desmoncus polyacanthos and Sabal palmetto, are widespread, with ranges extending well beyond the West Indian region. Most species, however, are endemic or near-endemic (reaching continental coasts). We recognize 118 taxa as strictly endemic to the West Indies.

The status of West Indian palms has been assessed before, either globally or by country. The first regional assessment was that of Dransfield et al. (1988), based on data amassed in the IUCN Threatened Plants Unit database. At that time the taxonomy of several West Indian genera was poorly understood. Consequently, many of the taxa in Dransfield et al. (1988) are no longer recognized, and the names on that list are difficult to reconcile with those on current floristic lists. The second 
conservation assessment was Johnson \& the IUCN/SSC Palm Specialist Group (1996), a global assessment that listed only those palms thought to be highly threatened; it did not assign a conservation assessment to other species. More recently, several publications have addressed the conservation status of palms within a particular geopolitical region (Henderson et al., 1990; Moya \& Leiva, 2000; Zona et al., 2003; Berzaín et al., 2005; Galeano \& Bernal, 2005).

Threats to native palms in the West Indies include land clearing for agriculture and construction, overexploitation for timber, thatch or other products, anthropogenic fires, habitat degradation, livestock, competition from introduced exotic plants, and introduced pathogens and pests. Of these, land clearing poses the greatest threat. Assessing the conservation status of palms in the West Indies is a critical first step in prioritizing conservation resources and activities. The need for an up to date, complete global assessment of the West Indian palms was the impetus for this paper.

\section{Methods}

The islands included in this assessment are the Bahamas Archipelago (including the Turks \& Caicos Islands), Cayman Islands, Cuba, Hispaniola, Jamaica, the Lesser Antilles, and Puerto Rico and the Virgin Islands (Fig. 1). We have used the taxonomy of the World Checklist of Palms (Govaerts \& Dransfield, 2005), along with the genera recognized by Dransfield et al. (2005), as these are the most up to date and are widely regarded as the arbiter of palm taxonomy. We included only those palms believed to be native to the region; introduced or naturalized species were excluded. We also considered one taxon, Zombia antillarum var. gonzalezii of the Dominican Republic, that was not included in Govaerts \& Dransfield (2005) either as a recognized taxon or synonym. We believe that, until its taxonomic status can be resolved, this taxon should not be excluded from assessment. One taxon listed by Govaerts \& Dransfield (2005), Copernicia x escarzana, was not included in our assessment, as we believe it to be synonymous with C. x burretiana. Copernicia yarey var. robusta was treated as a synonym of $C$. yarey by Govaerts \& Dransfield (2005) but we recognize and evaluate it as a distinct variety.

We used the IUCN Red List Categories and Criteria version 3.1 (IUCN, 2001, 2006) to assess the conservation status of each taxon. Our sources of data are published accounts of the palm flora, along with personal observations made during field work since 1985 . Field work in Cuba was by RV and ALS; field work elsewhere in the West Indies was by the remaining authors.

\section{Results}

Our Red List assessments for each taxon are presented in the Appendix with, for comparison, the Red List assessments of Dransfield et al. (1988), Johnson \& the IUCN/SSC Palm Specialist Group (1996), and the current global Red List status (IUCN, 2006). The number of taxa in each Red List category by island or island group and overall, summarized from our assessments in the Appendix, and also the number of taxa and endemic taxa by island or island group, are presented in Table 1. The 134 taxa are not uniformly distributed throughout the region. Of the 11 taxa that we assess as Critically Endangered nine occur in Cuba, which also has the greatest number of palm species, and two in Haiti. There are $118(88 \%)$ taxa strictly endemic to the West Indies. One hundred and nineteen taxa (89\%) occur in only one of the island areas considered in this assessment but of these, six (or $4 \%$ of the total West Indian taxa) also occur in areas outside the West Indies. A significant proportion of the remaining 113 island taxa are probably point endemics, i.e. with a restricted geographic range. The exact number of point endemics cannot be determined without further taxonomic study.

\section{Discussion}

\section{Extinct and Critically Endangered species}

Only one West Indian palm, Roystonea stellata, is categorized as Extinct. This palm was endemic to the Meseta de Maisí, in extreme eastern Guantánamo Province, Cuba. It was described from a single specimen by Brother León in 1943 but repeated exploration for the palm has failed to relocate it (Zona, 1991). In September 2005 RV searched for this palm and distributed photographs among many local people of the characteristic fruits of $R$. stellata but without success. $R$. stellata is not known to be in cultivation.

Attalea crassispatha is endemic to Haiti, where $<30$ adult palms persist in severely degraded habitats (Henderson et al., 1990; Timyan \& Reep, 1994). These palms are occasionally felled, and children eat the immature seeds. Seedlings are over-browsed by livestock. Conservation measures, including ex situ cultivation in Haiti and other countries, and livestock exclosures around mature palms, have been initiated (Timyan \& Reep, 1994), but long-term success cannot yet be evaluated.

Pseudophoenix lediniana is endemic to a limited area in Departement de l'Ouest, Haiti, where $<50$ adults survive (Henderson et al., 1990; Zona, 2002). The site is traditionally respected by the local people but lacks any legal protection. The palm fruits are gathered for animal feed (Read, 1968), and therefore the species' long-term viability is in doubt. The species is, however, widely 


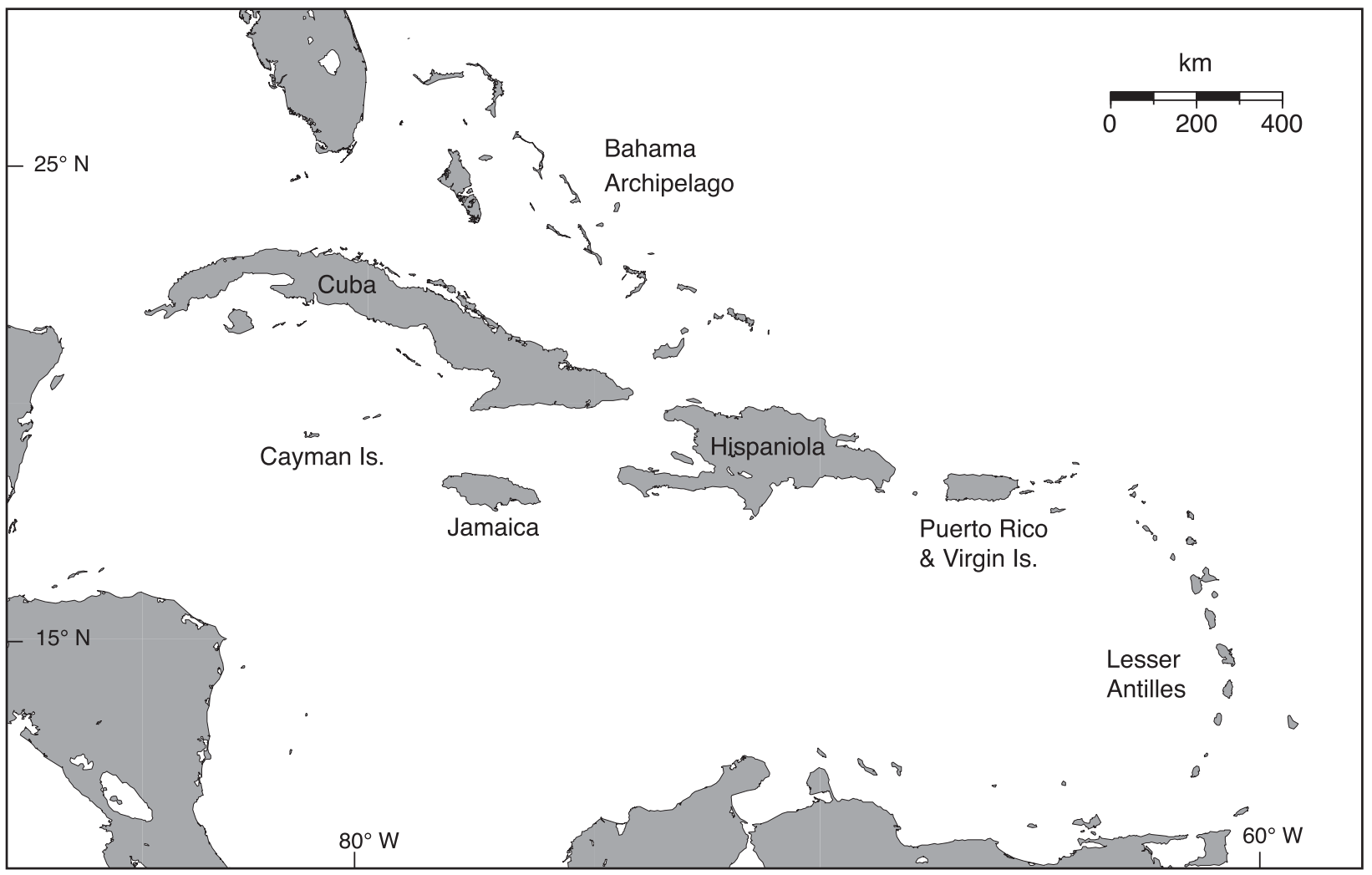

Fig. 1 The West Indies, showing the islands and island groups included in this conservation assessment of the palms.

cultivated in botanical gardens, where the potential for ex situ conservation exists.

Coccothrinax crinita ssp. crinita is endemic to western Cuba. Moya \& Leiva (2000) reported that only one population of 60 individuals was known in the wild. More recently, the population was found to comprise $c .1,000$ individuals (Rodríguez Alvarez, pers. comm.). The present threats to Coccothrinax crinita ssp. crinita include habitat degradation by fire and grazing. Overexploitation for broom and brush manufacture in the past, when the palm was abundant, contributed to the species' decline. The palm is grown in an ex situ collection at the National Botanic Garden, Havana, Cuba, which has an project to reintroduce $c .1,000$ young plants to the natural population using plants grown from seeds collected in situ.

Copernicia fallensis faces a high level of exploitation for fibres (R. Verdecia, pers. obs.). The exploitation is not believed to be sustainable, although the staff of Las

Table 1 The number (with \% in parentheses for totals) of West Indian palm taxa (see Appendix) in each IUCN Red List category (IUCN, 2001) by island or island group (Fig. 1), and overall, and also the total number of taxa and endemic taxa.

\begin{tabular}{|c|c|c|c|c|c|c|c|c|c|c|}
\hline \multirow[b]{2}{*}{ Island/island group } & \multicolumn{8}{|c|}{ Red List category $^{1}$} & \multirow{2}{*}{$\begin{array}{l}\text { Total no. } \\
\text { of taxa }\end{array}$} & \multirow{2}{*}{$\begin{array}{l}\text { No. of endemic } \\
\text { taxa }\end{array}$} \\
\hline & EX & EW & CR & EN & VU & NT & $\mathrm{LC}$ & DD & & \\
\hline Bahamas Archipelago & & & & & & & 6 & 2 & 8 & 2 \\
\hline Cayman Islands & & & & & & & 1 & 1 & 2 & 1 \\
\hline Cuba & 1 & & 9 & 16 & 17 & & 39 & 11 & 93 & 83 \\
\hline Hispaniola & & & 2 & 2 & 4 & & 15 & 8 & 31 & 18 \\
\hline Jamaica & & & & & & & 10 & 1 & 11 & 8 \\
\hline Lesser Antilles & & & & 1 & & & 9 & 2 & 12 & 1 \\
\hline Puerto Rico \& Virgin Islands & & & & & & & 9 & 1 & 10 & 0 \\
\hline Total $^{2}$ & $1(<1 \%)$ & 0 & $11(8 \%)$ & $19(14 \%)$ & $21(16 \%)$ & 0 & $57(42 \%)$ & $25(19 \%)$ & 134 & 113 \\
\hline
\end{tabular}

${ }^{1}$ EX, Extinct; EW, Extinct in the Wild; CR, Critically Endangered; EN, Endangered; VU, Vulnerable; NT, Near Threatened; LC, Least Concern; DD, Data Deficient

${ }^{2}$ Individual columns cannot be summed to arrive at the total as the range of some species includes more than one island or island group. 
Tunas Botanic Garden, Cuba, have begun a programme of education and awareness for local authorities and people living within the range of the species.

The remaining Critically Endangered taxa are known from only a few populations with limited extent of occurrence. These taxa may be regarded as point endemics. For example, Coccothrinax borhidiana is known only from a $1 \mathrm{~km}$ strip of coastal limestone scrub near Matanzas, Cuba (Moya \& Leiva, 2000). The precariousness of this population cannot be understated, as the area around the population is being disturbed and developed. The newly established botanic garden of Matanzas University is committed to the in situ and ex situ conservation of this species.

\section{Endangered and Vulnerable species}

Three of the 19 taxa that we categorize as Endangered, Gaussia spirituana, Reinhardtia paiewonskiana and Roystonea violacea, are believed to have population sizes of $<250$ adult palms and are therefore categorized using criterion D (IUCN, 2001). However, these species occur in areas not immediately threatened by agriculture, exploitation or forest clearing. The remaining species are categorized as Endangered because they exist in no more than five locations (criterion B2a) and their habitats are being degraded by human activities (B2b iii). Reinhardtia paiewonskiana is of particular concern because it is the only West Indian member of a genus that is otherwise confined to Mexico and Central America, and it is not yet known to be in ex situ collections. A new locality for Gaussia spirituana has been reported in Ciego de Ávila province of Cuba, and ex situ cultivation of the species is underway at the Sancti Spiritus Botanic Garden of Cuba (Rodríguez Fernández, pers. comm.)

The 21 taxa categorized as Vulnerable mostly have small populations estimated to be $<1,000$ mature adults (criterion D1), or the area of occupancy is $<20 \mathrm{~km}^{2}$ and subject to human disturbance or natural stochastic events (D2). In some cases, the population size may be as large as 10,000 adults but a $10 \%$ decline in the population is estimated within the next decade (C1) because the palms are harvested for sweet sap or the young leaves for making brooms. The Vulnerable Copernicia gigas, one of the largest palms of the genus, is managed and conserved in the protected area of Delta del Cauto, Cuba, where this palm is the principal nesting site of several bird species.

\section{Least Concern and Data Deficient species}

The 57 taxa categorized as Least Concern (i.e. not on the Red List) are generally widespread species with large populations, often found on many islands of the West Indies. Taxa that have smaller extents of occurrence are those found in montane areas that are unlikely to be disturbed by forest clearing for agriculture, residential or commercial development, or other human activities. The 25 Data Deficient taxa are species whose ranges, numbers and conservation status are currently unknown. These taxa should be given high priority for more detailed field work and subsequent conservation assessments.

\section{Taxonomic problems and conservation}

One of the greatest impediments to conservation assessments and action for West Indian palms is the taxonomic confusion surrounding certain species, a problem that is not unique to West Indian species. Because palms are large and require specialized collection techniques they are often under-represented in herbaria and have not been as thoroughly studied as most temperate zone plant species. The confused state of the taxonomy of the genera Coccothrinax and Copernicia is one reason why many of their species are assessed as Data Deficient.

Taxonomy potentially affects species' conservation status (Agapow et al., 2004). Consolidating several taxa into one, widespread taxon ('lumping') causes the recognition of larger areas of occupancy, more populations, and a greater number of adults, thus diminishing the conservation concern. Conversely, giving taxonomic recognition to subpopulations ('splitting') magnifies the conservation concern (Nixon \& Wheeler, 1990; Agapow et al., 2004; Herbert et al., 2004; Bernal \& Galeano, 2006). Ideally, taxonomic studies based on adequate sampling and explicit methods should precede any conservation assessment.

There are several examples from West Indian palms in which taxonomy has had a profound impact on conservation status. Calyptronoma rivalis was previously believed to be endemic to Puerto Rico, where it was threatened. Zona (1995) revised the genus and recognized that $C$. rivalis also occurs throughout much of Hispaniola; hence, the global threat to $C$. rivalis is diminished. Similarly, several species and infraspecific taxa in Pseudophoenix were recently combined into a widespread and somewhat variable Pseudophoenix sargentii (Zona, 2002), thus accounting for the reduced level of global concern in the present assessment. Prior to this the population of $P$. sargentii on Navassa Island was given varietal status. If this variety were still recognized it would be one of the most Critically Endangered palms in the region as only one individual remains (Zona, 2002).

Molecular diversity below the species level has not been assessed for any of the West Indian palms. Such studies, particularly of wide-ranging, common, and somewhat variable palm species are urgently needed. 
For example, Prestoea acuminata var. montana, Acrocomia aculeata, Sabal palmetto, P. sargentii and Acoelorraphe wrightii are sufficiently variable to suggest that molecular studies, coupled with detailed ecological and morphological studies, may reveal patterns of variation that correspond to species boundaries. There is already molecular evidence from a low-copy nuclear gene that at least two taxa should be recognized within the widespread and variable Acrocomia aculeata (Gunn, 2004). Morphological and ecological observations of Aiphanes minima on the island of Dominica suggest that two taxa are present (A. James, K. Laugengayer \& S. Zona, pers. obs.).

\section{The problem of hybrids}

Among West Indian palms the genus Copernicia is believed unique for its propensity to form fertile hybrids in the wild. The complex pattern of morphological variation, particularly the morphological intermediates that are found where two Copernicia species co-occur (Dahlgren \& Glassman, 1963; Moya \& Mayotte, 1996), strongly suggests hybridization. However, none of the putative natural hybrid populations have been analysed at the genetic level, and hybrid origin has not been unequivocally demonstrated.

The question of whether hybrids should be conserved is controversial (Allendorf et al., 2001; Maunder et al., 2004). We believe that the putative hybrids of Copernicia species in Cuba are valuable to the ecosystems in which they occur for the same reason that non-hybrid palms are important (keystone species, indicators of habitat quality, and usefulness to people). Therefore we evaluated the putative hybrid taxa and found them to be either Critically Endangered or Endangered. Hence there is urgency to our call for conservation and genetic studies of these putative hybrids.

\section{Conclusions}

There is an urgent need to conserve the palm flora of the West Indies, which is under threat from habitat disappearance and degradation. Remarkably, only one species, Roystonea stellata, is believed to be extinct. The greatest hindrance to conservation assessments is the inadequate state of knowledge for several palm genera, notably Acrocomia, Aiphanes, Coccothrinax and Copernicia. Taxonomic studies that include extensive field work, descriptions, keys and range maps are urgently needed so that species boundaries, areas of occupation and extents of occurrence can be established. Sustainable use and protection policies require adequate conservation data, which in turn require a good taxonomic base. However, until these taxonomic studies can be com- pleted we recommend that preliminary conservation assessments be made and that disputed taxa or populations be given conservation consideration.

Regional botanical gardens are playing a significant role in managing and monitoring in situ populations of threatened West Indian palms, in collaboration with government agencies, NGOs, and local conservation initiatives. There is scope for conservation support from regional botanical gardens (Maunder et al., 2001). At present $e x$ situ collections of several threatened palms are maintained in the National Botanic Garden (Havana, Cuba), Fairchild Tropical Botanic Garden (Florida, USA), Montgomery Botanical Center (Florida, USA) and Las Tunas Botanic Garden (Las Tunas, Cuba), among others. However, this ex situ institutional support will only be successful if matched by a commitment to secure viable wild populations through habitat conservation and, where appropriate, the application of recovery management to wild populations (Maschinski \& Duquesnel, 2007).

\section{Acknowledgements}

We thank Carlo Morici, who shared with us his data on Thrinax and Hemithrinax of Cuba.

\section{References}

Agapow, P.-M., Bininda-Emonds, O.R.P., Crandall, K.A., Gittleman, J.L., Mace, G.M., Marshall, J.C. \& Purvis, A. (2004) The impact of species concept on biodiversity studies. Quarterly Review of Biology, 79, 161-179.

Allendorf, F.W., Leary, R.F., Spruell, P. \& Wenburg, J.K. (2001) The problems with hybrids: setting conservation guidelines. Trends in Ecology and Evolution, 16, 613-622.

Bernal, R. \& Galeano, G. (2006) Endangerment of Colombian palms (Arecaceae): change over 18 years. Botanical Journal of the Linnean Society, 151, 151-163.

Berzaín Iturralde, R., Areces Berzaín, F., Lazcano Lara, J.C. \& González Torres, L.R. (2005) Lista Roja de la Flora Vascular Cubana. Jardín Botánico Atlático, Gijón, Spain.

Biodiversity Hotspots (2004) Caribbean Islands. Http:// www.biodiversityhotspots.org/xp/hotspots/caribbean/ [accessed 12 November 2004].

Dahlgren, B.E. \& Glassman, S.F. (1963) A revision of the genus Copernicia. 2. West Indian species. Gentes Herbarum, 9, 41-232.

Dransfield, J., Johnson, D. \& Synge, H. (1988) The Palms of the New World: A Conservation Census. IUCN-WWF Plants Conservation Programme, Publication no. 2, IUCN, Gland, Switzerland.

Dransfield, J., Uhl, N.W., Asmussen, C.B., Baker, W.J., Harley, M.M. \& Lewis, C.E. (2005) A new phylogenetic classification of the palm family, Arecaceae. Kew Bulletin, 60, 559-569.

Galeano, G. \& Bernal, R. (2005) Palmas. In Libro Rojo de Plantas de Colombia, Vol. 2. Palmas, Frailejones y Zamias (eds

E. Calderón, G. Galeano \& N. García), pp. 59-224. Instituto Alexander von Humboldt, Instituto de Ciencias Naturales de la Univirsidad Nacional de Colombia, Ministerio de 
Ambiente, Vivienda y Desarrollo Territorial, Bogotá, Colombia.

Govaerts, R. \& Dransfield, J. (2005) World Checklist of Palms. Royal Botanic Gardens, Kew, UK.

Gunn, B. (2004) The phylogeny of the Cocoeae (Arecaceae) with emphasis on Cocos nucifera. Annals of the Missouri Botanical Garden, 91, 505-522.

Henderson, A., Aubry, M., Timyan, J. \& Balick, M. (1990) Conservation status of Haitian palms. Principes, 34, 134-142.

Herbert, P.D.N., Penton, E.H., Burns, J.M., Janzen, D.H. \& Hallwachs, W. (2004) Ten species in one: DNA barcoding reveals cryptic species in the neotropical skipper butterfly Astraptes fulgerator. Proceedings of the National Academy of Sciences (USA), 101, 14812-14817.

Horst, O.H. (1997) The utility of palms in the cultural landscape of the Dominican Republic. Principes, 41, 15-28.

IUCN (1994) 1994 Categories and Criteria (version 2.3). IUCN, Gland, Switzerland [http://www.redlist.org/info/ categories_criteria1994.html, accessed 22 May 2007].

IUCN (2001) 2001 Categories and Criteria (version 3.1). IUCN, Gland, Switzerland [http://www.redlist.org/info/ categories_criteria2001.html, accessed 3 March 2005].

IUCN (2006) 2006 IUCN Red List of Threatened Species. IUCN, Gland, Switzerland [http://www.redlist.org, accessed 22 May 2007].

Johnson, D. (ed.) \& the IUCN/SSC Palm Specialist Group (1996) Palms: Their Conservation and Sustained Utilization. Status Survey and Conservation Action Plan. IUCN, Gland, Switzerland and Cambridge, UK.

Maschinski, J. \& Duquesnel, J. (2007) Successful reintroductions of the endangered long-lived Sargent's cherry palm, Pseudophoenix sargentii, in the Florida Keys. Biological Conservation, 134, 122-129.

Maunder, M., Hughes, C., Hawkins, J.A. \& Culham, A. (2004) Hybridization in ex situ collections. In Ex Situ Plant Conservation (eds E.O. Guerrant, K. Havens \& M. Maunder), pp. 325-364. Island Press, Washington, DC, USA.

Maunder, M., Lyte, B., Dransfield, D. \& Baker, W. (2001) The conservation value of botanic garden palm collections. Biological Conservation, 98, 259-271.

Moya, L., C.E. \& Leiva, S., A.T. (2000) Checklist of the palms of Cuba, with notes on their ecology, distribution and conservation. PALMS, 44, 69-84.

Moya, L., C.E. \& Mayotte, P.T. (1996) ‘Paradiso Principium' - A palm paradise in Cuba. Principes, 40, 152-155.

Nixon, K.C. \& Wheller, Q.D. (1990) An amplification of the phylogenetic species concept. Cladistics, 6, 211-223.

Read, R.W. (1968) A study of Pseudophoenix (Palmae). Gentes Herbarum, 10, 169-213.
Read, R.W. (1988) Utilization of indigenous palms in the Caribbean (in relation to their abundance). Advances in Economic Botany, 6, 137-143.

Smith, M.L., Hedges, S.B., Buck, W., Hemphill, A., Inchaustegui, S., Ivie, M.A., Martina, D., Maunder, M. \& Francisco-Ortega, J. (2004) Caribbean islands. In Hotspots Revisited (eds R.A. Mittermeier, P. Robles Gil, M. Hoffman, J. Pilgrim, T. Brooks, C. Goettsch Mittermeier, J. Lamoreux \& G.A.B. da Fonseca), pp. 112-118. CEMEX, Mexico City, Mexico.

Terborgh, J. (1986) Keystone plant resources in the tropical forest. In Conservation Biology (ed. M.E. Soulé), pp. 330-344. Sinauer, Sunderland, USA.

Timyan, J.C. \& Reep, S.F. (1994) Conservation status of Attalea crassispatha (Mart.) Burret, the rare and endemic oil palm of Haiti. Biological Conservation, 68, 11-18.

Zona, S. (1991) Notes on Roystonea in Cuba. Principes, 35, 225-233.

Zona, S. (1995) A revision of Calyptronoma (Arecaceae).

Principes, 39, 140-151.

Zona, S. (2002) A revision of Pseudophoenix. PALMS, 46, 19-38.

Zona, S., James, A. \& Maidman, K. (2003) The native palms of Dominica. PALMS, 47, 151-157.

\section{Appendix}

The appendix for this article is available online at http://journals.cambridge.org

\section{Biographical sketches}

The authors are members of the IUCN/SSC Palm Specialist Group, with interests in both ex situ and in situ conservation of palms throughout the world. Scott Zona is the head of Fairchild Tropical Botanic Garden's Palm Conservation Program and Chair of the IUCN/SSC Palm Specialist Group. Raúl Verdecia is director of the Las Tunas Botanical Garden. Angela Leiva is director of Cuba's National Botanical Garden and Chair of the IUCN/SSC Cuban Plants Specialist Group. Mike Maunder is director of Fairchild Tropical Botanic Garden and Chair of the IUCN/SSC Plant Conservation Sub-Committee. Carl E. Lewis works with molecular genetics of palms and palm informatics and is the creator of the Fairchild Guide to Palms (http://www. palmguide.org). 